\title{
Analysis of NOR distribution in cultivated and naturalized stocks of rainbow trout (Oncorhynchus mykiss)
}

\author{
Fábio Porto-Foresti ${ }^{1}$, Claudio Oliveira ${ }^{1}$, Yara A. Tabata ${ }^{2}$, Marcos G. Rigolino ${ }^{2}$ and Fausto Foresti ${ }^{1}$ \\ ${ }^{1}$ Departamento de Morfologia, Instituto de Biociências, Universidade Estadual Paulista, \\ campus de Botucatu, Botucatu, SP, Brazil. \\ ${ }^{2}$ Núcleo Experimental de Salmonicultura, Instituto de Pesca, Campos do Jordão, SP, Brazil.
}

\begin{abstract}
In salmonid species, nucleolar organizing regions (NORs) have frequently been found on a single chromosome pair. However, some other, smaller yet active NORs have also been described. In the present study, NORs were found to be located in different positions on the chromosomes of 12 rainbow trout samples (11 cultivated and one naturalized stocks). Three phenotypes were found: 1) NORs located on two submetacentric chromosomes, in a subterminal position on the short arm (AA); 2) NORs located on two submetacentric chromosomes, in a subterminal position on the long arm (BB); and 3) NORs located on two submetacentric chromosomes, one in a subterminal position on the short arm, and the other in a subterminal position on the long arm (AB). Phenotype AA was identified in individuals from ten cultivated stocks, phenotype $A B$ was identified in individuals from three cultivated stocks, and phenotype BB was found in one cultivated and one wild stock. Some aspects of the origin and the distribution of the different phenotypes are discussed.
\end{abstract}

Key words: NOR polymorphism, fish cytogenetics, rainbow trout.

Received: May 6, 2002; accepted: October 9, 2002.

\section{Introduction}

Salmonid fish were tentatively introduced in Brazil in the beginning of the twentieth century. In 1962, a large official program was set up, and rainbow trout eggs were imported from California (EUA), in order to start the culture of this species in fish farms, and also to introduce it into some rivers of the Serra da Bocaina (Rio de Janeiro and São Paulo), Serra da Mantiqueira (São Paulo), and other mountain fluvial systems, located in the northern region of the state of Santa Catarina (MacCrimmon, 1971).

Cytogenetic studies have shown that salmonid species frequently have a single chromosome pair with active nucleolus organizer regions (NORs) (Phillips and Ihssen, 1985; Phillips et al., 1986). However, additional NORs have been described in a few specimens (Phillips et al., 1989; Pendás et al., 1993). Fluorescence hybridization studies with $18 \mathrm{~S}$ probes in the brown trout, Salmo trutta, revealed that, in addition to larger aggregations of rDNA in one chromosome pair, 16 other, smaller, transcriptionally inactive regions were also present (Pendás et al., 1993).

Send correspondence to F. Porto-Foresti, Departamento de Morfologia, Instituto de Biociências, Universidade Estadual Paulista, campus de Botucatu, 18618-000 Botucatu, SP, Brazil. E-mail: fabio@ibb.unesp.br.
In the rainbow trout Oncorhynchus mykiss, several studies have shown that NORs are located in a subterminal position on the short arm of a submetacentric chromosome pair (Schmid et al., 1982; Phillips and Ihssen, 1985; Mayr et al., 1986; Ueda and Kobayashi, 1988; Lloyd and Thorgaard, 1988). Oliveira et al. (1996) observed, however, that rainbow trouts from Núcleo Experimental de Salmonicultura de Campos do Jordão, imported from California (USA) in the 1960's, exhibited NORs in a subterminal position on the long arm of a submetacentric chromosome pair (Table I).

In the present study, the Ag-NOR technique was used to determine and compare the chromosome location of the NORs in 11 rainbow trout samples obtained from cultivated and naturalized stocks in the states of São Paulo, Rio de Janeiro and Minas Gerais.

\section{Material and Methods}

Cytogenetic analysis was performed on rainbow trout (Oncorhynchus mykiss) samples from twelve different cultivated stocks and one sample captured in the wild (naturalized) (Table I). Some specimens of each stock were marked with magnetic tags and kept in tanks at Núcleo 
Table I - List of the rainbow trout (Oncorhynchus mykiss) stocks employed for cytogenetic analyses and identification of NOR phenotypes.

\begin{tabular}{|c|c|c|c|c|c|}
\hline \multirow[t]{2}{*}{ Sampling site } & \multirow[t]{2}{*}{ Sample code } & \multirow[t]{2}{*}{ Sample origin ${ }^{1}$} & \multicolumn{2}{|c|}{ Number of specimens } & \multirow[t]{2}{*}{ NOR phenotype $^{6}$} \\
\hline & & & Obtained & Analyzed & \\
\hline $\begin{array}{l}\text { Núcleo Experimental de Salmonicultura } \\
\text { de Campos do Jordão, São Paulo }\end{array}$ & Stock 1 & California, USA $^{2}$ & - & 19 & $\mathrm{BB}$ \\
\hline $\begin{array}{l}\text { Núcleo Experimental de Salmonicultura } \\
\text { de Campos do Jordão, São Paulo }\end{array}$ & Stock 2 & Isle of Man, England & 30 & 10 & $\mathrm{AA}$ \\
\hline $\begin{array}{l}\text { Salmonicultura N R, Sapucaí Mirim, } \\
\text { Minas Gerais }\end{array}$ & Stock 3 & Mount Shasta, USA & 40 & 10 & AA \\
\hline $\begin{array}{l}\text { Salmonicultura N R, Sapucaí Mirim, } \\
\text { Minas Gerais }\end{array}$ & Stock 4 & Kamloops, Canada & 30 & 10 & AA \\
\hline $\begin{array}{l}\text { Núcleo Experimental de Salmonicultura } \\
\text { de Campos do Jordão, São Paulo }\end{array}$ & Stock 5 & Denmark $^{4}$ & 50 & 10 & $\mathrm{AA}$ \\
\hline $\begin{array}{l}\text { Aquacultivo Montenegro, Teresópolis, } \\
\text { Rio de Janeiro }\end{array}$ & Stock 6 & Teresópolis ${ }^{3}$ & 20 & 10 & $\mathrm{AA}-\mathrm{AB}$ \\
\hline $\begin{array}{l}\text { Salmonicultura Hotel Fazenda São João, } \\
\text { Nova Friburgo, Rio de Janeiro }\end{array}$ & Stock 7 & Nova Friburgo ${ }^{3}$ & 25 & 10 & $\mathrm{AA}$ \\
\hline $\begin{array}{l}\text { Salmonicultura Hotel Fazenda São João, } \\
\text { Nova Friburgo, Rio de Janeiro }\end{array}$ & Stock 8 & USA & 20 & 10 & AA \\
\hline $\begin{array}{l}\text { Salmonicultura Hotel Fazenda São João, } \\
\text { Nova Friburgo, Rio de Janeiro }\end{array}$ & Stock 9 & Denmark $^{5}$ & 30 & 10 & $\mathrm{AA}$ \\
\hline AQUA Ltda, Bananal, Rio de Janeiro & Stock 10 & Serra da Bocaina ${ }^{3}$ & 25 & 8 & $\mathrm{AA}-\mathrm{AB}$ \\
\hline $\begin{array}{l}\text { Núcleo Experimental de Salmonicultura } \\
\text { de Campos do Jordão, São Paulo }\end{array}$ & Stock 11 & Japan & 30 & 10 & $\mathrm{AA}-\mathrm{AB}$ \\
\hline Gavião River, Bananal, São Paulo & Stock 12 & São José dos Barreiros, SP & 15 & 6 & BB \\
\hline
\end{tabular}

${ }^{1}$ The origin of samples at each fish farm was certified by landowners and managers.

${ }^{2}$ Stock kept isolated in Campos do Jordão for over 30 years and studied by Oliveira et al. (1996).

${ }^{3}$ Stocks kept isolated for over 10 years.

${ }^{4}$ Stock recently (less than 5 years ago) imported by Associação Brasileira de Truticultores.

${ }^{5}$ Stock recently (less than 5 years ago) imported by the Hotel Fazenda São João.

${ }^{6} \mathrm{AA}=$ NORs located in a subterminal position on the short arms of two submetacentric chromosomes; $\mathrm{BB}=\mathrm{NORs}$ located in a subterminal position on the long arms of two submetacentric chromosomes; and $\mathrm{AB}=$ NORs located on two submetacentric chromosomes, one in a subterminal position on the short arm, and the other in a subterminal position on the long arm.

Experimental de Salmonicultura de Campos do Jordão, São Paulo, Brazil.

Direct suspensions of kidney cells (Foresti et al., 1993) were used to analyze the chromosomal characteristics of the individuals, after prior injection of the fish with a yeast cell suspension, to increase the number of metaphase cells (Lozano et al., 1988). The procedure used to identify NORs was originally described by Howell and Black (1980).

\section{Results and Discussion}

Studies including the identification of NORs have appointed them as important cytogenetic markers for aquaculture research (Fergunson et al., 1995). Moreover, several investigations have demonstrated that polymorphic NOR phenotypes are inherited (Mikelsaar et al., 1977; Markovic et al., 1978; Henderson and Bruere, 1980; Arruda and Monteagudo, 1989).

In the present study, three NOR phenotypes were found: 1) NORs located in a subterminal position on the short arms of two submetacentric chromosomes (AA); 2) NORs located in a subterminal position on the long arms of two submetacentric chromosomes (BB); and 3) NORs located on two submetacentric chromosomes, one in a subterminal position on the short arm, and the other in a subterminal position on the long arm (AB).

The AA phenotype was the most common, and was found in specimens from ten cultivated stocks (Table I and Figures 1a-h, j, 1). This observation is in accordance with most of data published on NOR distribution in rainbow trout (Schmid et al., 1982; Phillips and Ihssen, 1985; Mayr et al., 1986; Ueda and Kobayashi, 1988; Lloyd and Thorgaard, 1988; Phillips et al., 1989). Phenotype AB was observed in $20 \%$ of the specimens from stock $6,20 \%$ from stock 10, and 30\% from stock 11 (Table I and Figures 1i, k, $\mathrm{m})$. This pattern has not been described in any previous study.

Taking into account that phenotype BB is a characteristic of the rainbow trouts from stock 1 (Oliveira et al., 1996 - Table I, Figure 1n), the occurrence of phenotype AB in some individuals of stocks 6,10 , and 11 may be due to hy- 


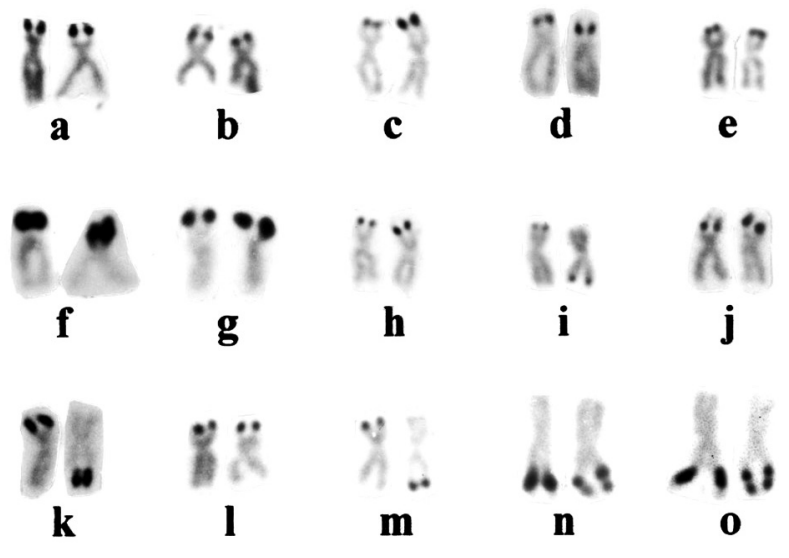

Figure 1 - Location of the nucleolar organizing regions (NORs) in samples of rainbow trout (Oncorhynchus mykiss) introduced in Brazil. a) Isle of Man (stock 2); b) Mount Shasta (stock 3); c) Kamloops (stock 4); d) Denmark (Associação Brasileira de Truticultores) (stock 5); e) Nova Friburgo (stock 7); f) USA (stock 8); g) Denmark (Hotel Fazenda São João) (stock 9); h) Teresópolis (stock 6); i) hybrid sample from Teresópolis (stock 6); j) Serra da Bocaina (stock 10); k) hybrid sample from Serra da Bocaina (stock 10); 1) Japan (stock 11); m) hybrid sample from Japan (stock 11); n) California, USA (stock 1); o) Gavião river (stock 12).

bridization processes between fish from these stocks and fish from stock 1. Considering the managing process of the stocks involved, this was expected, because eggs and fries of the rainbow trouts from stock 1 have been widely distributed throughout trout farms in the states of São Paulo, Rio de Janeiro and Minas Gerais, where this species is cultivated.

Cytogenetic analysis revealed that all fish of stock 12 exhibited phenotype BB (Figure 1o). It was also observed that one of the submetacentric chromosomes had a double mark at the terminal portion of its long arm, similar to that found by Oliveira et al. (1996) in stock 1 .

The presence of phenotype BB and of a characteristic chromosome with two NOR segments in the individuals from stock 1 (from Núcleo Experimental de Salmonicultura de Campos do Jordão) and stock 12 (Gavião river) suggests that both stocks have a common ancestor. This observation agrees with MacCrimmon (1971), who reported that the rainbow trout samples introduced in the mountain areas of São Paulo state came from California in the early 1960's. The study of other naturalized populations and the use of alternative molecular markers may lead to a better understanding of the relationships among rainbow trout stocks in Brazil.

\section{Acknowledgments}

The authors are grateful to R. Devidé and A. L. Alves for technical assistance, to Dr. P.M. Galetti Jr., Dr. O. Moreira Filho, Dr. N. Castagnoli and Dr. J.F. Lui for critical review of the original manuscript. Funds supporting this study were provided by FAPESP.

\section{References}

Arruda MV and Monteagudo LV (1989) Evidence of Mendelian inheritance of the nucleolar organizer regions in the Spanish common rabbit. J Hered 80:85-86.

Fergunson A, Taggart JB, Prodöhl PA, Mcmeel O, Thompson C, Stone C, Mcginnity P. and Hynes RA (1995) The applications of molecular markers to the study and conservation of fish populations with special reference to Salmo. J Fish Biol 47:103-126.

Foresti F, Oliveira C and Almeida-Toledo LF (1993) A method for chromosome preparations from large specimens of fishes using in vitro short treatment with colchicine. Experientia 49:810-813.

Henderson LM and Bruere AN (1980) Nucleolus organizer region location and "ring" chromosomes in the bharal. Experientia 36:176-177.

Howell WM and Black DA (1980) Controlled silver-staining of nucleolus organizer regions with a protective colloidal developer: a 1-step method. Experientia 36:10141015.

Lloyd MA and Thorgaard GH (1988) Restriction endonuclease banding of rainbow trout chromosomes. Chromosoma 96:171-177.

Lozano R, Rejon CR and Rejon MR (1988) A method for increasing the number of mitoses avaliable for cytogenetic analysis in rainbow trout. Stain Tech 66:335-338.

MacCrimmon HR (1971) World distribution of rainbow trout (Salmo gairdneri). J Fish Res B Can 28:663-704.

Mayr B, Rab P and Kalat M (1986) Localisation of NORs and counterstain-enhanced fluorescence studies in Salmo gairdneri and Salmo trutta (Pisces, Salmonidae). Theor Appl Genet 71:703-707.

Markovic VD, Worton RG and Berg JM (1978) Evidence for the inheritance of silver-stained nucleolus organizer regions. Hum Genet 41:181-187.

Martínez P, Vias A, Bousa C, Arias J, Amaro R and Sánchez L (1991) Cytogenetical characterization of hatchery stocks and natural populations of sea and brown trout from northwestern Spain. Heredity 66:9-17.

Mikelsaar AV, Schwarzacher HG, Schnedl W and Wagenbichler P (1977) Inheritance of Ag-stainability of nucleolus organizer regions. Investigations in 7 families with trisomy 21 . Hum Genet 38:183-188.

Oliveira C, Foresti F, Rigolino MG and Tabata YA (1996) Paracentric inversion involving a NOR-bearing chromosome of rainbow trout (Oncorhynchus mykiss): electron microscopy studies of the synaptonemal complex. Caryologia 49:335-342.

Pendás AM, Morán P and García-Vazquez E (1993) Multi-chromosomal location of ribosomal RNA genes and heterochromatin association in brown trout. Chrom Res 1:63-67.

Phillips R and Ihssen PE (1985) Chromosome banding in salmonid fish: nucleolar organizer regions in Salmo and Salvelinus. Can J Genet Cytol 27:433-440.

Phillips RB, Zajicek KD and Utter FM (1986) Chromosome banding in salmonid fishes: nucleolar organizer regions in Oncorhynchus. Can J Genet Cytol 28:502-510. 
Phillips RB, Pleyte KA and Ihssen PE (1989) Patterns of chromosomal nucleolar organizer regions (NOR) variation in fishes of the genus Salvelinus. Copeia 1989:47-53.

Porto-Foresti F, Oliveira C, Gomes EA, Tabata YA, Rigolino MG and Foresti $\mathrm{F}$ (in press) Investigation of a lethal effect associated with a polymorphism involving the NOR-bearing chromosomes in rainbow trout (Oncorhynchus mykiss). J World Aquacult Soc.
Schmid M, Loser C, Schmidtke J and Engel W (1982) Evolutionary conservation of a common pattern of activity of nucleolous organizer during spermatogenesis in vertebrates. Chromosoma 86:149-179.

Ueda T and Kobayashi J (1988) Disappearance of Ag-NORs originated from brown trout in the allotriploid female rainbow trout and male brown trout. Proc Japan Acad 63B:51-55. 